\title{
Teacher Research: Exploring Teachers' Personal Epistemology through Narrartive Lens. A Colombian Case
}

\author{
Diego Fernando Ubaque Casallas ${ }^{1}$ \\ ${ }^{1}$ Pontificia Universidad Javeriana, Bogotá, Colombia \\ Correspondence: Diego Fernando Ubaque Casallas, Pontificia Universidad Javeriana, Transversal 4 \#42-00, \\ Colombia. E-mail: diegoubaque@gmail.com
}

Received: August 1, 2017 Accepted: September 10, 2017 Online Published: September 12, 2017

doi: 10.5539/elt.v10n10p114 URL: http://doi.org/10.5539/elt.v10n10p114

\begin{abstract}
This narrative inquiry study looked into four teachers' life stories regarding their teaching practice. The study explored teachers' experiences in pre-while and after stages when being observed by an academic supervisor in a binational but non- profit English center in Bogota, Colombia. By attempting to explore the possible forms of teachers' knowledge, the study took on narrative inquiry as the research approach to explore how teachers approach and navigate personal and fixed epistemologies regarding teaching. Findings revealed that teachers' personal epistemologies are shaped by elements like agreement and negotiation of meaning when supervisors assess/evaluate or discuss issues of the teaching practice. Based on the findings, I argue teachers' personal epistemologies are driven by collaborative situated activities teachers engage in.
\end{abstract}

Keywords: narrative inquiry, collaboration, supervision, life story

\section{Introduction}

Professional development is a phenomenon that has a crucial importance for teachers to advance in their career professionally (Yurtseven \& Altun, 2017). On this, teaching has become in essence a critical endeavor of reflection. Although teaching English as a foreign language has gone through the rapid development of teaching, English teachers have become more and more aware of the need of improving their practices to reach a certain level of effectiveness in their classes. Regarding this, "effectiveness does not mean or refer to being perfect or to giving a wonderful performance in the classroom, but bringing out the best in students" (Leah, 2017, p. 84); then, this demanding yet analytical effort has extended teaching to a more collaborative approach that goes beyond the exclusive use of either the communicative approach or grammar-translation method to deal with everything that concerns to teaching a language.

The form, use, and content of the target language is not anymore the unique angle from where teachers see and understand their job as language teachers. Indeed, teaching has become a more personal enterprise where personal theories about the nature of language and language learning have become the source of the way things are done in the classroom, and which provide the ground for teachers to shape and reshape what they do. As for this, supervision has emerged as an instrument to support and guide teachers in their efforts to teaching and improvement.

Bearing this in mind, it could be contended that even though "supervision is expected to improve classroom performance and develop staff professionally" (Farhat, 2016, p. 421), it may fall short if teachers multiple ways of learning and knowing are to be framed within this scope. Then, this study will not discuss how teachers' theories of knowledge and knowing processes impact their interactions with students and their teaching behaviors; instead, it will lay emphasis on teacher's epistemological beliefs emerging in life stories since knowing about teacher construction of knowledge is relevant for the local ELT community to understand how personal epistemology impact teachers' own beliefs.

\section{Theoretical Considerations}

\subsection{Narrative Inquiry}

This study understands narrative inquiry as a negotiated research practice. Narrative inquiry is then quintessentially an ontological approach where experiences are continuously interactive, resulting in changes in both people and the contexts in which they interact (Dewey, 1938). For Caine, Estefan and Clandinin (2013), "It is 
through this experience that people's lives are composed and recomposed in relation with others who are also living storied lives." Therefore, narrative inquiry opens up space to enter into the "ordinary experience" of EFL teachers and their practices in order to understand and explore the artistry of their lives lived (Dewey, 1934).

Since narrative inquiry uses different means to understand experience, this study takes on teacher's ' personal stories to understand how they approach and navigate personal and fixed epistemologies regarding teaching. In as much as the story is how people make sense of their existence (Clandinin, Huber, \& Murphy, 2011 ), it seems relevant to explore stories by becoming narrative taking the form of discourse reveal teaches' ways of knowing.

As for this, the narrative discourse contained in stories is useful in describing and interpreting the meaning of life experiences as well as it is essential to make a story culminate in learning and transforming the personal epistemology that, in this study, surrounds and underpins the teaching practice.

\subsection{Supervision: The Critical Lens}

Teacher knowledge and development may be successfully constructed through "relationship-based approaches" (Cunningham, Etter, Platas, Wheeler, \& Campbell, 2015, p. 62). In teacher education, supervision has emerged from the figure of an instructor, evaluator, coach or mentor (Hawkey 1997) to contribute to teacher's professional growth. Even though the concept of supervision has been described by using a myriad of aims, such as to support, teach, debrief, coach, assess, and to challenge the student (Davys \& Beddoe, 2000), within the teacher education spectrum, supervision has been mainly regarded as a mechanism to verify curricula. Surprisingly, this idea of professional development may be too narrow to understand supervision, making it an elusive term in education (Diaz-Maggioli, 2003).

Sparks (2002) argues that professional development should be embedded in the daily lives of teachers, with strong administrative support and use of strategies that are tailored to their specific needs. Then, supervision would admit categories of teachers as pre-service, novice, tenured, and veteran (Nolan \& Hoover, 2003) to differentiate several approaches to professional development. This distinction notwithstanding, supervision is still a murky dimension of professional development that needs more clarification if it is taken into account that schools, universities, and English institutions engage in supervisory activities that are aimed at certification and improvement of in-service teachers.

As far as this study is concerned, supervision is regarded as a collaborative mechanism by which the supervisor and the supervisee get to negotiate, construct and produce new knowledge from the inspection, discussion and modification of observed teaching practices. Nonetheless, this definition of supervision is relevant since it overlaps and expands on the one the institution where the study was conducted has. Then, supervision can be framed within clinical supervision. In this model, supervision can be viewed as an interactive rather than directive process (Kalule \& Bouchamma, 2014), and whose primary purpose is "the professional development of teachers" (Acheson \& Gall, 2003). Therefore, supervision is in this study a multidimensional process that is dependent upon multiple factors that should result in improved personal and professional capabilities (Drennan \& Clarke, 2009).

\subsection{Epistemology as a Collaborative Endeavor}

According to Huberman (1989), teachers' careers are characterized by cycles of conflict/resolution that lead to growth and development. Interestingly, some researchers have interchanged terms such as theories and philosophies with beliefs, acknowledging that these are personal constructions (e.g., Simmons et al., 1999) that help teachers make sense of their practice. Being this said, it is impossible to avoid referring to the beliefs individuals hold about the nature and processes of knowledge that are known as one's personal epistemology (Burr \& Hofer, 2002), and that are an inherent yet emerging component of teachers' professional development.

This study takes on a sociocultural perspective that conceives teacher learning as a social practice that is situated and intrinsically personified (Jurasaite-Harbison, 2009) to situate (synonym) teachers as agents that through interactions construct their knowledge rather than acquire it. Thus, personal epistemology, seen from this perspective, is the study of people's thinking about knowledge and about how people know (Hofer \& Bendixen, 2006). However, it assumes that as teachers as agents learn through interactions, constructing their knowledge rather than acquiring it (Jurasaite-Harbison, 2009, p. 300), any personal epistemology that emerges from the teacher practice is in essence collaborative.

\section{Context and Contextualization of the Study}

The manuscript presents the results of a qualitative narrative study that looked into four EFL language teachers' teaching experiences through the collection of their life stories as in-service teachers. In this regard, four English language teachers members of a private but non-profit English institution in Bogota, Colombia and whose ages ranged from 28 to 36 six years old, participated for a period of more than six months in a number of four life story 
interviews.

Since this study regarded teachers' learning as the knowledge of cognitive processes that in a way emerges as thinking processes that include cognitive activity control (Wellman, 1985), the study started by exploring teachers' individual awareness of their cognitive activities related to the teaching practice within the supervision system.

This system aims to provide support in the use of the instructional methods of teaching the institution, where the study was conducted, believes in. This support takes place through professional learning sessions that normally seek to encourage teachers to reflect upon classes observed and that are based on a checklist that seeks to guarantee teachers follow the program principles.

Teachers were surveyed on their opinion about the supervision system of the institution as well as on the importance, it has for and the benefits it brings to their teaching practice. Results show that although teachers have an instrumentalized perspective of what supervision entails -they hold the view that it serves the purpose of gauging whether teachers are complying with the principles of the institution- they also perceive supervision as a formative space where they can develop and improve their teaching practices, gain more pedagogical knowledge, and ultimately grow professionally. Teachers assert that when the supervision process is well designed and carried out properly, outcomes are positive for everyone involved in the teaching-learning process.

I consider that it works as it helps teachers improve their teaching practices. [sic]

It is a way of evaluating and guiding teacher's class performance according to standards proposed by an institution. [sic]

One of the main purposes of the supervision system is to monitor the quality of education. It serves as a tool used by the institution to gauge whether teachers stick to its principles and philosophy. I consider that a well-designed supervision system is pivotal to create a culture of cooperation among stakeholders. [sic]

Survey, teachers' answers; question 1, What do you think about the supervision system?

It has helped a lot. As I have been part of all the programs every time, I have something to improve on. [sic]

The impact has been positive; I have learnt how to manage a class, with a coherent organization and with clear objectives. [sic]

It has definitely affected my own practice. I get to listen to different perspectives on what can be done in the classroom. I respect what other have to say and in doing so I learn for other's experiences. [sic]

I have learned how to teach effectively, grammar, pronunciation and other items I have found hard to comply with [sic]

Survey, teachers' answers; question 3, How has supervision impacted your teaching practice?

As stated below, some teachers linked supervision to professional growth, as a mechanism to improve their teaching practice. Moreover, there is an evident perception of how learning emerges from being monitored or supervised by others. Arguably, there is a sense of community and personal growth that emerges from the interaction with others and the need to improve the teaching practice itself.

As far as this study is concerned, personal epistemology is the core to explore and understand professional growth. Therefore, and as this study looked to understand and document how teachers approach and navigate personal and fixed epistemologies regarding teaching, teachers' stories of their experience teaching and learning within a supervision system seem to be in need of exploration.

\section{Methodological considerations}

This study took on methodological principles of narrative research. Since narrative studies are framed within a qualitative approach to locate different sets of interpretative materials turning the world into a series of representations (Denzin \& Lincoln, 2011), to get to know more in detail the life stories collected, the methodological approach used to analyze data collected was of narrative inquiry. According to Barkhuizen, Benson and Chik (2014) narrative inquiry brings storytelling and research together either by using stories as research data or by using storytelling as a tool for data analysis or presentation of findings. Echoing this, Ubaque (2015) argues that "a narrative mode of knowing may explain experience way better instead of breaking it into pieces" this is why, narrative inquiry was undoubtedly the only methodology that could provide access to four teachers' teaching practices as lived experiences exploring how they produce, negotiate and modify personal knowledge when supervision mediates the teaching practice. 


\section{Data Analysis and Findings}

This study aimed to understand how teachers approach and navigate personal and fixed epistemologies regarding teaching. Then, in light of the life stories, collected data were inspected by making use of analytical and coding elements of grounded theory (Charmaz, 2006). Being this approach neither reductionist or positivistic, the analytic elements of grounded theory were mostly geared towards abstracting and relating categories to each other in the data analysis.

Therefore, the study started by exploring teachers' insights regarding supervision. To understand these insights, the study made use of the life story interview. Atkinson (2002, p. 123) explains, "life story interviewing is a qualitative research method for gathering information on the subjective essence of one person's entire life that is transferable across disciplines". Thus, by approaching teachers from the story, they chose to tell (Atkinson, 1998); data revealed that teachers were aware of the system where they were immersed. This awareness was, to some extent, the result of knowledge they had acquired to comply with the methodological requirements of the institution for which they were working.

\section{P 2: PARTICIPANT 2 - 2:1 [IEE: The supervision system can...] (3:5) (Super)}

Codes: [Knowledge to comply with]

IEE: The supervision system can be perceived as a way for the institution to gauge teachers' performance and how they actually or how they do what, you know... things we are supposed to do in terms of the institution's philosophy or rules or policies. The excerpt above provides evidence of/onhow the participant perceives the system of supervision.

Even though this sort of awareness may seem a bit instrumental, it is in essence an element to assert that teachers know that supervision works as a mechanism to guarantee teachers' compliance with the principles the institution claims to be essential in teaching and learning English. Supervision, seen from this perspective, plays more an internal institutional process rather than a professional one; a notion that according to Daresh (2001) makes of supervision "a process of overseeing the ability of people to meet the goals of the organization in which they work" (p. 25) instead of boosting people's own abilities to become producers of knowledge.

This view notwithstanding, supervision seemed to shape positively teachers' practice. As for this, supervision is known to foster teacher growth in view of improved performance in teaching and improved student learning (Nolan \& Hoover 2011); then, teachers also claimed that knowledge produced by them could be, in general terms, a knowledge to comply with, yet this would be knowledge that could be defined as an instrumentalized awareness of the conditions needed to succeed within a specific context allowing them to a) adapt to the requirements of the institution; and $b$ ) become better teachers.

\section{P 4: PARTICIPANT 4 - 4:2 [IEE: Yeah, it has definitely c...] (7:7) (Super)}

Codes: [Knowledge to comply with] [Supervision as system]

IEE: Yeah, it has definitely changed because at the beginning I felt like I had to learn how to do the steps that are requested here. And I did not remember some things and I was like so mechanic like class preparation and assessment, and I began to be quite boring in my classes. So, but then, with time, that I actually internalized and understood the principles of the program, I began to use it in a more natural way. However, at the beginning it was hard to adapt. However, I think it has helped me a lot in terms of the clarity of my ideas when I teach, and I see that the principles have sense. I feel if they work.

Then, if teachers are to follow some principles to make sure students learn, their practices would be linked directly to students' academic achievement, intrinsic motivation, and learning efficacy (Goddard et al., 2000); arguably, this institutional approach to teaching could be linked to the notion of teaching efficacy since it refers to "a judgment about capabilities to influence students' engagement and learning" (Woolfolk, 2004, p. 1). Supervision would be then a means for teaching efficacy to be the main outcome for teachers even if knowledge teachers hold appears to be instrumentalized. Nonetheless, this knowledge to comply with seems as well to shape and limit at the same time teacher's own style of teaching by standardizing teaching practice in a set of teaching principles.

If teaching efficacy is grounded in the need of achieving certain capabilities to organize and execute courses of action, it could be contended then that what is narrated above would position teacher's knowledge to comply with as given type of performance that guarantees teaching outcomes but hinders teachers' own production of knowledge. This claim is better supported in the following narrative:

P 6: PARTICIPANT 4-2ND INTERVIEW - 6:7 [That was the first negotiation...] (10:10)

Codes: [Knowledge I modify based on my reflection/practice] 
That was the first negotiation that I had to do and the flexibility of my creativity because definitely if we have principles to follow there are things that I would love to do and I can't do due to the methodology that is proposed by the institution. Therefore, that is something else I have had to negotiate but I try to... not to negotiate but try to modify in order to keep a balance between what I am and what the institution needs from me.

This model of instructional supervision described above appears to be linked and integrated to teacher's personal style of knowing and doing. Yet this sort of knowledge they have to comply could be perceived as something that has the potential to hinder teacher's own production of knowledge, it could be contended that it also follows the idea even though that teachers, as key actors in the learning process, internally control what is or is not learned (Zepeda, 2007) they develop their skills throughout different routes of action.

These routes of actions teachers choose and are exposed to create a need of adapting to the new conditions they encounter as professionals. Then, learning seen from these routes of actions can be seen as a multifaceted process that can either foster teachers' personal or professional grow or hinder teachers' epistemological beliefs in classroom pedagogy (White, 2000).

As noted at the outset of this paper, this study aimed to understand how teachers approach and navigate personal and fixed epistemologies regarding teaching. Therefore and as supervision helps frame epistemologies teachers approach and navigate as professionals in the context of the study, it turns out to be relevant to mention that in a supervision model, observation is of those routes of knowledge where teachers as supervisees and supervisors as observers walk through together to reach a some sort of professional growth.

The observation this study accounts for is the type of peer observation that is scheduled ahead by the supervisor without informing teachers when it was going to be carried out. The main purpose of observing teacher's practices is to collect quantitative data on what was happening in the classroom and therefore be able to provide teachers with enough feedback to improve their class performance in light of some classroom principles adopted by the institution.

Bell $(2005$, p. 3) defines peer observation of teaching as: "collaborative, developmental activity in which professionals offer mutual support by observing each other teach; explaining and discussing what was observed; sharing ideas about teaching; gathering student feedback on teaching effectiveness; reflecting on understandings, feelings, actions and feedback and trying out new ideas". This sort of approach to class performance is based on a reciprocal relationship between supervisors and teachers working together. Arguably, this approach could be seen a democratic rather than authoritarian model to understand teachers' practice.

However, as this study expected to understand how teachers approach and navigate personal and fixed epistemologies regarding teaching, this observation component of supervision appeared to be relevant when understanding teachers' knowledge(s).

\begin{tabular}{|c|c|c|c|c|}
\hline ACTIVITIES AND INSTRUCTIONS & $\mathbf{E}$ & VG & G & NI \\
\hline Each activity is articulated to meet the & & & & \\
\hline $\begin{array}{l}\text { Activities are structured along a sequen } \\
\text { steps to ensure students' success. }\end{array}$ & & & & \\
\hline Each activity provides students with eno & & & & \\
\hline Processes and outcomes are assessed. & & & & \\
\hline Instructions are clear and sequenced. & & & & \\
\hline Instructions are modeled and assessed. & & & & \\
\hline
\end{tabular}

Image 1. Supervision checklist. Activities and instructions

ASSESSMENT
\begin{tabular}{|l|}
\hline It is on-going. \\
\hline It is profile based. \\
\hline It is accurate and objective. \\
\hline Different assessment techniques are evident in class. \\
\hline Teacher's, self, and peer assessment are implemented \\
\hline Criteria for assessment are specified before the assessment moment. \\
\hline Assessment criteria are meaningful and appropriate for the activity. \\
\hline An action plan is proposed after each assessment moment. \\
\hline $\begin{array}{l}\text { Teacher collects information from students' work while they are on task } \\
\text { and use it to give feedback. }\end{array}$ \\
\hline
\end{tabular}

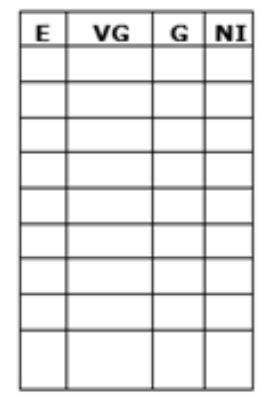

Image 2. Supervision checklist. Assessment 
Image 1 and 2 are parts of a larger supervision checklist teachers in this study were to comply with. The areas here range from personal to instructional aspects that have proven to be effective in the specific EFL classes where this study took place. These areas, according to the institution, serve to narrow down the scope of the observations carried out by supervisors. To align this with the peer- observation stage described before, it is important to mention that supervisors are the ones who go to teachers' classes to observe their practices. Supervisors do so since they are seen as having research knowledge, management and interpersonal skills, and are innovative; problem solvers and resource orientated (Vilkinas, 2002) and therefore are capable of not instrumentalizing the observation checklist.

The checklist above and the observation process carried out appears to be problematic between supervisors and supervisees. This position towards observation opens a door to debate the extent supervision contributes to teachers' learning. The narrative below reveals how one of the participants of the study perceives this process of observation.

\section{P 3: PARTICIPANT 3 - 3:9 [So, I understand that the day ...] (32:32) (Super)}

\section{Codes: [Knowledge to comply with] [Supervision as system]}

Therefore, I understand that the day the supervisor goes, he has to evaluate everything, that everything is there, but as a practice, as an everyday practice, it can be hard, especially for students. Of course, I know that they have to monitor everything. However, it is also important that teachers know that that is something they do not necessarily have to do every single day. Because I did it and my students got really really bored of classes, and I tried to change like the way, the methodology, and the way I presented the assessment or the way I asked about the action plans, but what they noticed that it was the same repetition every day. So, exactly, to tell teachers that the idea is to use all these, eh, all these tools, but that they can play with them that they can modify; on some days they do something, the next day they try something different for not to make classes monotonous.

Although, it is known that an important role of teacher professional development is to raise both the competence and confidence of teachers (Valdmann, Rannikmae, \& Holbrook, 2016, p. 286) the peer-observation or peer coaching stage within the supervision model would not be completely fulfilling this aim. As seen in the narrative above, knowledge teachers have to comply with seems to be restricted to the repetition of set routines that to some extend cannot be part of an ideal or natural environment for teacher's professional growth. On this, even though there are numerous benefits of peer observation described in the literature including: improvements to teaching practice, development of confidence to teach and learn more about teaching, transformation of educational perspectives (Bell, 2005), there must be a shift regarding teachers' belief about this collaborative approach to professional growth.

At this stage of peer-observation or coaching supervisors are figures of power that go to monitor teacher's compliance with the program principles. They play an important role in providing a model of peer and self-assessment for those teachers exposed to the supervision lens. On this, other emerging aspect data revealed is that teachers feel some sort of pressure when they are observed. Participant four perceived that rather than supporting and providing feedback to each other in a co-equal and affable manner (Ackland, 1991), this process of peer observation or coaching was instead conditioning teacher's performance.

This finding can be extended in the narrative below:

\section{P 4: PARTICIPANT 4 - 4:8 [IEE: You know, it's just that ...] (22:22) (Super)}

Codes: [Knowledge to comply with] [Supervision as system]

IEE: You know, it is just that when we are supervised...the pressure, yes, I feel pressure. It is not natural. Yes. Because to be honest, we only do all the things that, we have to do just when we are being observed. Yes. In addition, because, I mean, we cannot, I mean, like to be predictable, students. No, that is not natural in a class. In addition, well, the pressure does not help. Yes. So, but it is necessary, yes, I mean, they have to see we are actually doing what we have to do. Yes? However, I think it does not guarantee students learn, and it does not guarantee if teachers are actually doing that because teachers prepare themselves. So, we feel like, OK, we are going to be observed, so let us do everything. In addition, at the time, I am being observed I will do it.

This narration recognizes the downside of observing teachers just to guarantee their fulfillment of principles. This would mean that observing teachers in this non-natural way is definitely hindering teachers' capability to make choices and act regarding their immediate reality of teaching (Martin, 2004). However, it could be also said that it is in this non-natural environment where teachers' personal epistemologies regarding teaching emerge since they learn to: a) mix their own beliefs regarding teaching with the ones the institution holds; b) reflect upon what is needed to succeed within a specific academic community; and c) adapt to the new circumstances. 
These personal epistemological beliefs help us to understand more about effective learning and teaching (Schommer-Aikens, 2006) in the context of supervision since they mediate other knowledge and beliefs (Schommer-Aikens, 2004) that teacher have negotiate with. Interestingly, more of these epistemologies is also found when in the data teachers' narratives brought up the notion of feedback, other stage of the supervision model the institution where this study took place takes on.

Since providing teachers with information about their classes is aimed to improve a given classroom performance (Hattie \&Timperley, 2007), feedback sessions seemed to be understood by teachers as a mechanism to reflect upon their in class performance. However, this stage, as reported in this study, is acknowledged a complex skill (Prins et al., 2006), that it is needed to improve teaching practices and which aim would be of bridging the gap between the current situation and the intended goals (Hattie \& Timperley, 2007).

In the narratives collected, teachers made evident a discomfort with this stage of the supervision model. The narrative below may explain more in detail this discomfort.

P 2: PARTICIPANT 2 - 2:7 [I mean I guess also depends on...] (23:23) (Super) Codes: [Knowledge that emerges/ is modified by from the interaction with someone else]

I mean I guess also depends on how... how the supervisor conveys this kind of feedback for how... how everything comes across. Sometimes some supervisors like talk and talk. I do not know what the words I am looking for maybe they are...they talk down on you. Then you know they feel that they own knowledge and when you know when you perceive that you know you can lose respect. However, when actually supervisors work with you on your weaknesses but in a way that is supportive yet assertive I think is a great way for you to grow up. Know.

This narrative shows how teachers' own beliefs get to interplay with those of the supervisor. To avoid puzzling over the concept of belief and to connect this to the notion of emerging epistemologies, it must be said a belief refers to "a proposition which may be consciously or unconsciously held, is evaluative in that it is accepted as true by the individual, and is therefore imbued with emotive commitment" (Borg, 2001, p. 186); then, the role of -who possess knowledge is above questioned.

If 'teachers' beliefs about learning and teaching thus represent propositions about learning and teaching that teachers hold to be true" (de Vries et al, 2013, p. 214) the narrative above positions the feedback session more as a moment of confrontation. However, teachers' professional knowledge, overall classroom approach and actual practices differ according to the types of beliefs teachers embrace. This dissonance opens the door for emerging epistemologies as well.

As seen above, teachers were somehow aware of the knowledge they had and disagrees on the supervisors, as the one possesses knowledge. The narrative of other participant of this study contests the narrative below. As for this, one participant also mentioned the collaborative nature of the production of new knowledge when supervision mediates the teaching practice.

\section{P 3: PARTICIPANT 3 - 3:6 [IEE: OK, after the class is ob...] (25:25) (Super)}

Codes: [Knowledge that emerges/ is modified by from the interaction with someone else] [Supervision as system]

IEE: OK, after the class is observed, the supervisor has a meeting with the teacher and he describes what the teacher did in the class in a very detailed way. In addition, he starts describing the class and giving feedback about each moment. In addition, he also observes not only how teacher behaves in class, but also how students participate, eh and how the teacher faces difficulties with students, with low-achievers, especially. In addition, I find that that feedback moment with the supervisor is meaningful because you have the opportunity to ask questions about your practice, about special cases, and the idea is to create an action plan. Therefore, it is something that we do with students, and that we have to do in our process as teachers. Eh, you need to know how to face those difficulties and the supervisor gives some ideas to face those things.

Although this collaborative construction of knowledge seems to be rather imposed, it cannot be denied that such constructive view of learning and teaching require a strong conceptual understanding of general pedagogical knowledge and content knowledge. In closing this, teachers may not be fully aware of the personal epistemological assumptions that they hold, but it seems they are aware of the fact they possess some sort of theory that come into play when engaged in justifying or evaluating knowledge claims.

\section{Final Thoughts}

Even though people have different conceptions of the nature of knowledge and the nature of knowing (Hofer \& Pintrich, 1997), it is a fact that the most useful professional development should focus on active teaching. As far as 
this study was concerned, teachers" personal epistemology drove an essential component for teacher's development.

Professional development seemed to occur "implicitly in often unanticipated situations and in unrecognized ways" (Evans, 2014, p. 181) that teachers made evident when reflecting on their teaching practice; learning from their practice; therefore, epistemology, seen from this perspective, is a metacognitive process. There is also evidence in this study to suggest that epistemological beliefs are related to the metacognitive capacities of individuals to engage in personal reflection and analysis about their understandings and use of knowledge. In this study, the use of knowledge would range from theory-based practice to imposed constructions of "one's best practice".

Even though the finding above may seem a bit too simplistic, it helps understand that teachers approach and navigate personal and fixed epistemologies regarding teaching from a collaborative stand. In other words, any sort of effective professional learning occurred in collaboration with others (Blankstein et al., 2007). As a closing remark, professional development, seen from the supervision lens, should involve the creation of opportunities for teachers to build pedagogical and content knowledge, co-construct and enact new visions of practice (Nelson \& Slavit 2008). This would allow teachers to provide opportunities for the negotiation of different perspectives and meanings among those who teach and supervise teaching. Moreover, if supervision is to be used to guarantees teachers' fulfilment of any institutional principle regarding teaching, it is suggested teachers' experiences be taken into consideration in order to either bring about changes within the supervision system or promote thought and discussion regarding how teachers' own epistemologies can be used to improve the institutional principles on teaching.

\section{References}

Ackland, R. (1991). A review of the peer coaching literature. Journal of Staff Development, 12(1), 22-6.

Atkinson, R. (1998). The life story interview. Thousand Oaks, CA: Sage Publications. https://doi.org/10.4135/9781412986205

Atkinson, R. (2002). The life story interview. In J. F. Gubrium, \& J. A. Holstein (Eds), Handbook of Interview Research: Context \& Method (pp. 121-140). Sage Publications, Inc., Thousand Oaks, CA.

Bandura, A. (1997). Self-efficacy: the exercise of control. New York: Freeman.

Barkhuizen, G., Benson, P., \& Chik, A. (2014). Narrative inquiry in language teaching and learning research. New York, NY: Routledge.

Bell, M. (2005). Peer observation partnerships in higher education. NSW, Australia: Higher Education Research and Development Society of Australasia Inc.

Blankstein, A. M., Houston, P. D., \& Cole, R. W. (2007). Soul of educational leadership: Sustainin professional learning communities. Thousand Oaks: Corwin Press.

Borg, M. (2001), Teachers' beliefs. ELT Journal, 55(2), 186-8. https://doi.org/10.1093/elt/55.2.186

Burr, J. E., \& Hofer, B. K. (2002). Personal epistemology and theory of mind: deciphering young children's beliefs about knowledge and knowing. New Ideas in Psychology, 20(2-3), 199-224. https://doi.org/10.1016/S0732-118X(02)00010-7

Caine, V., Estefan, A., \& Clandinin, D. J. (2013). A return to methodological commitment: reflections on narrative inquiry. Scandinavian Journal of Educational Research, 57(6), 574-586. https://doi.org/10.1080/00313831.2013.798833

Charmaz, K. (2006). Constructing grounded theory. A practical guide through qualitative analysis. London: Sage.

Cunningham, A. E., Etter, K., Platas, L., Wheeler, S., \& Campbell, K. (2015). Professional development in emergent literacy: a design experiment of teacher study groups. Early Childhood Research Quarterly, 31, 62-77. https://doi.org/10.1016/j.ecresq.2014.12.002

Clandinin, D. J., Huber, J., \& Murphy, M. S. (2011). Familial curriculum making: re -shaping the curriculum making of teacher education. International Journal of Early Ghildhood Education, 77(1), 9-31.

Daresh, J. C. (2001). Supervision as a proactive leadership. Prospect Heights, IL: Wavweland Press.

Davys, A., \& Beddoe, L. (2000). Supervision of students: a map and a model for the decade to come. Social Work Education, 19, 437-449. https://doi.org/10.1080/026154700435968

Denzin, N. K., \& Lincoln, Y. S. (2011). Introduction: The discipline and practice of qualitative research. The sage handbook of qualitative research. Thousand Oaks, CA: Sage. 
de Vries, S., Wim J. C. M. van, d. G., \& Ellen, P. W. A Jansen. (2013). Teachers' beliefs and continuing professional development. Journal of Educational Administration, 51(2), 213-231. https://doi.org/10.1108/09578231311304715

Dewey, J. (1934). Art as experience. New York: Berkley Publishing Group.

Dewey, J. (1938). Experience and education. New York: Collier Books.

Diaz, M. G. (2003). Fulfilling the promise of professional development. LATEFL Issues, 4-5.

Drennan, J., \& Clarke, M. (2009). Coursework master's programmes: the student's experience of research and research supervision. Studies in Higher Education, 34(5), 483-500. https://doi.org/10.1080/03075070802597150

Farhat, A. (2016). Professional development through clinical supervision. Education, 136(4), 421-436.

Flavell, J. H. (1979). Metacognition and cognitive monitoring: a new area of cognitive developmental inquiry. American Psychologist, 34, 906-911. https://doi.org/10.1037/0003-066X.34.10.906

Evans, L. (2014). Leadership for professional development and learning: enhancing our understanding of how teachers develop. Cambridge Journal of Education, 44(2), 179-198. https://doi.org/10.1080/0305764X.2013.860083

Hofer, B. K., \& Pintrich, P. R. (1997). The development of epistemological theories: Beliefs about knowledge, knowing, and their relation to learning. Review of Educational Research, 67, 88-140. https://doi.org/10.3102/00346543067001088

Huberman, M. (1989). La vie des enseignants. Evolution et bilan d'une profession. Neûchatel, Switzerland: Delachaux.

Goddard, R. D., Hoy, W. K., \& Woolfolk Hoy, W. (2000). Collective teacher efficacy: Its meaning measure, and impact on student achievement. American Educational Research Journal, 37(2), 479-507. https://doi.org/10.3102/00028312037002479

Hawkey, K. (1997). Roles, responsibilities, and relationships in mentoring: A literature review and agenda for research. Journal of Teacher Education, 48, 325-335. https://doi.org/10.1177/0022487197048005002

Hattie, J., \& Timperley, H. (2007). The power of feedback. Review of Educational Research, 1(77), 81-112. https://doi.org/10.3102/003465430298487

Hofer, B. K. (2006). Domain specificity of personal epistemology: resolved questions, persistent issues, new models. International Journal of Educational Research, 45, 85-95. https://doi.org/10.1016/j.ijer.2006.08.006

Jurasaite-Harbison, E. (2009). Teachers' workplace learning within informal contexts of school cultures in the United States and Lithuania. Journal of Workplace Learning, 21(4), 299-321. https://doi.org/10.1108/13665620910954201

Kalule, L., \& Bouchamma, Y. (2013). Teacher supervision practices: what do teachers think? International Studies in Educational Administration (ISEA), 40(3), 91104.

Leah, C. (2017). Teaching English from Traditional to Modern. Scientific Journal of Humanistic Studies, 9(16), 84-86.

Martin, J. (2004). Self-regulated learning, social cognitive theory, and agency. Educational Psychologist, 39, 135-145. https://doi.org/10.1207/s15326985ep3902_4

Nelson, T., \& Slavit, D. (2008). Supported teacher collaborative inquiry. Teacher Education Quarterly, 35(1), 99-116.

Nolan, J., \& Hoover, L. (2003). Teacher supervision and evaluation: theory into practice. New York: Wiley.

Nolan, J., \& Hoover, L. (2011). Teacher supervision and evaluation: Theory into practice (3rd ed.). New York: Wiley.

Prins, F. J., Sluijsmans, D. M. A., \& Kirschner, P. A. (2006). Feedback for general practitioners in training: quality, styles and preferences. Advances in Health Sciences Education, 11(11), 289-303. https://doi.org/10.1007/s10459-005-3250-z

Schommer-Aikinsmer-Aikens, M. (2004). Explaining the epistemological belief system: Introducing the embedded systemic model and coordinated research approach.Educational Psychologist, 39(1), 19-29. https://doi.org/10.1207/s15326985ep3901_3 
Schommer-Aikens, M., \& Easter, M. (2006). Ways of knowing and epistemological beliefs: combined effect on $\begin{array}{llll}\text { academic } & \text { Eerformance. }\end{array}$ https://doi.org/10.1080/01443410500341304

Simmons, P. E., Emory, A., Carter, T., Coker, T., Finnegan, B., Crockett, D., ... Labuda, K. (1999). Beginning teachers: beliefs and classroom actions. Journal of Research in Science Teaching, 36, 930-954. https://doi.org/10.1002/(SICI)1098-2736(199910)36:8\%3C930::AID-TEA3\%3E3.3.CO;2-E

Sparks, D. (2002). Designing powerful staff development for teachers and principals. Oxford, OH: National Staff Development Council.

Ubaque, D. (2015). Life stories: a way to explore language learners' narrative experiences and identities in an EFL context. Revista Folios, 1(43), 153-164. https://doi.org/10.17227/0123487043folios153.164

Wellman, H. (1985). The origins of metacognition. In D. L. Forrest-Pressley, E. MacKinnon, \& T. G. Waller (Eds.), Metacognition, Cognition, and Human Performance (Volume 1- Theoretical Perspectives, chapter 1). Academic Press, Inc.

Valdmann, A., Rannikmae, M., \& Holbrook, J. (2016). Determining the effectiveness of a CPD programme for enhancing science teachers' self-efficacy towards motivational context-based teaching. Journal of Baltic Science Education, 15(3), 284-297.

Van Eekelen, I. M., Vermunt, J., \& Boshuizen, H. P. A. (2006). Exploring teachers' will to learn. Teaching and Teacher Education, 22(4), 408-23. https://doi.org/10.1016/j.tate.2005.12.001

Vilkinas, T. (2002). The PhD process: the supervisor as manager. Education and Training, 44(3), 129-137. https://doi.org/10.1108/00400910210424337

White, B. C. (2000). Pre-service teachers' epistemology viewed through perspectives on problematic classroom situations. Journal of Education for Teaching, 26, 279-306. https://doi.org/10.1080/713676891

Woolfolk, H. A. (2004). Self-efficacy in college teaching. Essays on teaching excellence. Toward the Best in the Academy, 15, 8-11.

Yurtseven, N., \& Altun, S. (2017). Understanding by design (UbD) in EFL teaching: teachers' professional development and students' achievement. Educational Sciences: Theory \& Practice, 17(2), 437-461. https://doi.org/10.12738/estp.2017.2.0226

Zepeda, S. (2007). Instructional supervision: applying tools and concepts. New York: Eye on Education.

\section{Copyrights}

Copyright for this article is retained by the author(s), with first publication rights granted to the journal.

This is an open-access article distributed under the terms and conditions of the Creative Commons Attribution license (http://creativecommons.org/licenses/by/4.0/). 